\title{
СТРАТЕГІЧНЕ УПРАВЛІННЯ ІННОВАЦІЙНИМ РОЗВИТКОМ СІЛЬСЬКОГОСПОДАРСЬКИХ ПІДПРИЕМСТВ НА ЕКОЛОГІЧНИХ ЗАСАДАХ
}

\section{STRATEGIC MANAGEMENT OF INNOVATIVE DEVELOPMENT IN AGRICULTURAL ENTERPRISES ON ECOLOGICAL PRINCIPLES}

\author{
Чернікова Наталія Миколаївна \\ кандидат економічних наук, доцент, \\ Полтавський державний аграрний університет \\ ORCID: https://orcid.org/0000-0002-0079-6411 \\ Бондаренко Ірина Олексіївна \\ здобувач освітнього ступеня "Бакалавр", \\ Полтавський державний аграрний університет \\ ORCID: https://orcid.org/0000-0001-5514-8238 \\ Окопний Максим Миколайович \\ здобувач освітнього ступеня "Магістр", \\ Полтавський державний аграрний університет \\ ORCID: https://orcid.org/0000-0003-4409-9121
}

\author{
Chernikova Nataliia, Bondarenko Iryna, Okopnyi Maksym \\ Poltava State Agrarian University
}

\begin{abstract}
Стаття присвячена питанням стратегічного управління інноваційним розвитком сільськогосподарських підприємств на екологічних засадах. У роботі доведено важливість поєднання понять "стратегічне управління", “інноваційний розвиток" та "екологічні засади діяльності" для забезпечення сталого розвитку окремих підприємств, галузей та країни в цілому. Встановлено, що екологічне спрямування інноваційного розвитку є одним 3 основних стратегічних завдань підприємств. 3 метою розробки стратегічних напрямків такого розвитку в статті проведено аналіз інноваційної діяльності сільськогосподарських підприємств на сучасному етапі. Надано оцінку їх екологічного стану та визначено коло проблем, що перешкоджають переходу діяльності підприємств на екологічні засади. Розроблено рекомендації щодо практичної реалізації запропонованих стратегій.

Ключові слова: стратегії, стратегічне управління, екологічні засади, інноваційний розвиток, сільськогосподарські підприємства.
\end{abstract}

Статья посвящена вопросам стратегического управления инновационным развитием сельскохозяйственных предприятий на экологических основах. В работе доказана важность объединения понятий "стратегическое управление", "инновационное развитие" и "экологические основы деятельности" для обеспечения устойчивого развития отдельных предприятий, отраслей и страны в целом. Установлено, что экологическая направленность инновационного развития является одним из основных стратегических заданий предприятий. С целью разработки стратегических направлений такого развития в статье проведен анализ инновационной деятельности сельскохозяйственных предприятий на современном этапе. Дана характеристика их экологического состояния и определен круг проблем, которые препятствуют переходу деятельности предприятий на экологические основы. Разработаны рекомендации относительно практической реализации предложенных стратегий.

Ключевые слова: стратегии, стратегическое управление, экологические основы, инновационное развитие, сельскохозяйственные предприятия.

The article is devoted to the issues of strategic management of innovative development in agricultural enterprises on ecological principles. The work proves the importance of combining the concepts of «strategic management», «innovative development» and «environmental principles» to ensure sustainable development of individual enter- 
prises, industries and the country as a whole, a general description of these concepts is provided. It is established that the ecological direction of innovative development is one of the main strategic tasks of enterprises, as the problems of environmental protection are relevant today for both Ukraine and the world. In order to elaborate strategic directions for such development, the innovative activities of agricultural enterprises at the current stage are analyzed in the article. The analysis revealed that in recent years there has been a decline in innovation performance of agricultural enterprises. An assessment of their ecological condition is given and the range of problems that avert the transition of enterprises to environmental principles is identified. The aims of the state ecological policy are given as a basis for the development of ecological strategies of individual enterprises and industries. The advantages of ecologically oriented strategic management of an agricultural enterprise are determined. A model of strategic management of innovative development of agricultural enterprises on ecological principles has been created, which includes innovative, environmental and management strategies, the combination of which allows to solve a set of strategically important tasks for the country and synergistic effect from their rational combination. Recommendations for the practical implementation of the proposed model have been developed. There are provided conclusions on possible positive consequences in case of transition of agricultural enterprises to the proposed model of strategic management, in particular: maintaining high technical and technological level of enterprises, compliance of product quality and management models with international standards, improving the image and reputation of domestic enterprises, gaining a strong position in the world market etc.

Keywords: strategies, strategic management, environmental principles, innovative development, agricultural enterprises.

Постановка проблеми. Останніми роками все більше загострюється проблема антропогенного впливу на навколишнє середовище. У зв'язку з погіршенням стану довкілля, екологізація виробництва набуває особливої актуальності у всьому світі. Ресурсозбереження, ощадливі технології, екологічно чисте та безвідходне виробництво стають сьогодні основними стратегічними завданнями для підприємств різних сорер та галузей діяльності. Значущість даної проблеми для сільськогосподарської галузі підсилюється ії стратегічною важливістю задля забезпечення економічної та продовольчої безпеки країни та її громадян. Тому, й інноваційний розвиток підприємств даної галузі має бути екологічно спрямованим, що сприятиме підвищенню безпечності та конкурентоспроможності продукції, виходу на зовнішні ринки тощо. Питання екологізації, як основного напрямку інноваційного розвитку аграрного виробництва $\epsilon$ сьогодні дуже актуальним та потребує пошуку шляхів його вирішення.

Аналіз останніх досліджень і публікацій. Вирішенню питань інноваційного розвитку сільськогосподарських підприємств на екологічних засадах присвячено праці таких науковців, як М.О. Багорка, В. Білінська, К.О. Прокопенко, О.В. Шубравська, Н.І. Юрченко. Питанням стратегічного управління інноваційним розвитком підприємств різних галузей приділяється увага в роботах В.Я. Брич, К.Ю. Вергал, О.Д. Гудзинського, С.М. Судомип, Т.О. Гуренко, К.В. Ковтуненко, М.Є. Рогоза, Х.А. Снігур, Н.М. Тисько, Я.О. Шпак.

Виділення невирішених раніше частин загальної проблеми. Проблеми стратегіч- ного управління екологічно спрямованим інноваційним розвитком саме сільськогосподарських підприємств залишаються ще не достатньо дослідженими. Тому, окремі аспекти потребують детального вивчення та розробки відповідної стратегії.

Формування цілей статті. Метою статті $\epsilon$ розробка управлінських стратегій інноваційного розвитку сільськогосподарських підприємств на екологічних засадах.

Виклад основного матеріалу дослідження. Поняття "стратегічне управління", "інноваційний розвиток" та "екологічні засади діяльності" неможливо розглядати сьогодні окремо одне від одного. Будь-яке підприємство має свої управлінські стратегії, які багатьма вченими визначаються як перелік правил, управлінських дій спрямованих на досягнення певної мети в майбутньому $[1 ; 5 ; 9]$. Інноваційний тип розвитку треба розуміти сьогодні як використання нововведень у всіх сорерах та галузях діяльності 3 метою підвищення ефрективності виробництва, управління та конкурентоспроможності. А екологічна політика, в свою чергу, є важливою складовою економічної політики. Поєднання вище наведених понять не тільки в теорії, але й на практиці дозволить досягти стійкого розвитку окремих підприємств, галузей та країни в цілому.

Аналіз інноваційної діяльності сільськогосподарських підприємств показав, що формування та практичне втілення інноваційної моделі їх розвитку залежить від: наявності та ефрективності інноваційного потенціалу (в т. ч. науково-технічних працівників); розробки інноваційної продукції (технік та тех- 
нологій, сортів рослин та порід тварин, матеріалів, методів, теорій та ін.); обсягів срінансування інноваційної діяльності 3 різних джерел. Але, за офріційними матеріалами Державної статистики та Міністерства освіти і науки України, протягом останніх років спостерігається скорочення даних показників, що свідчить про деградацію наукового потенціалу, зниження інноваційної активності та рівня ії фрінансування (таблиця 1).

Деякі науковці виділяють фрактори, що негативно відбиваються на стані інноваційної діяльності сільськогосподарських підприємств, а саме: використання лише готових спеціалізованих вітчизняних та закордонних розробок та відсутність власних інноваційних продуктів; незбалансованість інноваційної діяльності за сорерами виробництва, зокрема, у галузі рослинництва переважають розробки продуктові (удосконалення насіннєвого та посадкового матеріалу, біопестициди, біодобрива, спеціалізована сільськогосподарська техніка), а у тваринництві - це, переважно, інноваційні технології (утримання, годівлі та забою худоби та птиці, надою молока та ін.). Інноваційний тип розвитку сільськогосподарських підприємств сприятиме зростанню продуктивності праці у галузі, економії всіх видів ресурсів, зростанню обсягів виробництва, підвищенню конкурентоспроможності та ефрективності виробництва за рахунок його перебудови та техніко-технологічної переоснащеності. Дуже важливою $є$ участь держави у створенні сприятливих умов для інноваційної діяльності шляхом запровадження фрінансово-економічних стимулів такої діяльності, розвитку відповідної інфрраструктури (маркетингової, консалтингової, інсрормаційної та ін.), а також шляхом запровадження різних законодавчих ініціатив.

Проблеми збереження довкілля $€$ також одним 3 основних стратегічних завдань багатьох країн світу, а до найважливіших екологічних питань в глобальному масштабі можна віднести: збереження якості атмосферного повітря, охорони водних, земельних та лісових ресурсів, надр, запобігання різкій зміні клімату тощо. Впровадження еколого орієнтованого підходу в управлінні $€$ актуальним та здійснюється на сучасному етапі як в Україні, так і за її межами. Проте, існують певні проблеми, які стримують перехід вітчизняних підприємств на екологічні засади управління та фрункціонування:

- застаріла система моніторингу довкілля;

- низькі темпи практичної реалізації державної екологічної політики;

- недостатня інвестиційна підтримка процесу запровадження екологічно безпечних та ресурсозберігаючих технологій;

- застарілість основних фрондів;

- великий обсяг транспортних перевезень;

- неналежне зберігання та використання небезпечних речовин та ін.

Якщо до недавнього часу екологічні фрактори розглядались вченими, науковцями та практиками переважно як фрактор ризику для підприємства, то на сьогодні він вважається стратегічно важливим чинником, який додає суб'єктам господарювання додаткові можливості в розширенні ринків збуту, підвищенні іміджу та репутації підприємств, збільшенні кількості потенційних клієнтів, а також в підвищенні ефективності господарювання.

Найбільшим забруднювачем навколишнього середовища вважається промисловість, але сільське господарство також чинить значний негативний вплив, зокрема через: потрапляння залишків мінеральних добрив та засобів захисту рослин у ґрунти, ґрунтові та поверхневі води; промислове забруднення при виробництві агрохімікатів; зараження ґрунту та атмосорерного повітря відходами тваринницьких фрерм; виснаження ґрунтів та зростання дефіциту водних ресурсів; створення небезпеки для здоров'я та життя людей через надмірне використання мінеральних добрив при виробництві про-

\section{Показники інноваційної діяльності сільськогосподарських підприємств}

Таблиця 1 3a 2017-2020 pp.

\begin{tabular}{|l|c|c|c|c|}
\hline \multicolumn{1}{|c|}{ Показники } & $\mathbf{2 0 1 7}$ р. & $\mathbf{2 0 1 8}$ р. & $\mathbf{2 0 1 9}$ р. & $\mathbf{2 0 2 0}$ p. \\
\hline $\begin{array}{l}\text { 1. Кількість науково-технічної продукції створеної } \\
\text { НААН України за рахунок загального фронду, всього }\end{array}$ & 2677 & 1836 & 1895 & 1725 \\
\hline $\begin{array}{l}\text { 2. Кількість працівників, задіяних у науково-технічних } \\
\text { дослідженнях і розробок у сільськогосподарській галузі, осіб }\end{array}$ & 7451 & 7428 & 6508 & 6216 \\
\hline $\begin{array}{l}\text { 3. Відсоток фрінансування сільськогосподарської галузі науки } \\
\text { за рахунок усіх джерел від загального обсягу фінансування, \% }\end{array}$ & 6,2 & 5,8 & 5,6 & 4,5 \\
\hline
\end{tabular}


Таблиця 2

Внесення мінеральних та органічних добрив під посіви сільськогосподарських культур у 2000-2019 роках, кг/га

\begin{tabular}{|l|c|c|c|c|c|}
\hline \multicolumn{1}{|c|}{ Показники } & $\mathbf{2 0 0 0}$ р. & $\mathbf{2 0 0 5}$ р. & $\mathbf{2 0 1 0}$ р. & $\mathbf{2 0 1 5}$ р. & $\mathbf{2 0 1 9}$ p. \\
\hline $\begin{array}{l}\text { Внесення мінеральних добрив } \\
\text { на одиницю площі с.-г. угідь, кг/га }\end{array}$ & 6,7 & 13,4 & 25,6 & 34,1 & 56,3 \\
\hline $\begin{array}{l}\text { Внесення органічних добрив } \\
\text { на одиницю площі с.-г. угідь, кг/га }\end{array}$ & 692,9 & 320,3 & 239,5 & 238,5 & 274,3 \\
\hline
\end{tabular}

Джерело: побудовано авторами на основі [10]

дукції сільського господарства та ін. Так, протягом 2000-2019 років площа сільськогосподарських угідь в Україні зберігається на рівні 41,5-41,7 млн га, хоча спостерігається підвищення кількості використаних мінеральних добрив різних видів в розрахунку на 1 га сільськогосподарськихугідь 3 6,7 кг/гау 2000 році до 56,3 кг/га у 2019 році. Водночас використання органічних добрив скоротилось з 692,9 кг/га у 2000 році до 274,3 кг/га у 2019 році. Динаміку даних показників наведено у таблиці 2.

Разом 3 тим спостерігається скорочення витрат на охорону навколишнього середовища у всіх галузях, й у сільському господарстві даний показник знизився з 86363,4 тис грн у 2019 році, до 125240,5 тис грн у 2017 році.

Дослідження показують, що не існує єдиної стратегії для всіх підприємств, але розроблення стратегій розвитку сільськогосподарських підприємств має велике значення для забезпечення конкурентоспроможності та дов- гострокового успіху на ринку та мають базуватись на стратегічних цілях державної екологічної політики, які наведено на рисунку 1.

Враховуючи особливості сільськогосподарської галузі визначимо переваги екологоорієнтованого управління сільськогосподарськими підприємствами, які буде покладено в стратегію розвитку підприємств даної галузі. До їх числа слід віднести:

- збереження та покращення стану земельних та водних ресурсів, шляхом зменшення обсягу використання пестицидів, отрутохімікатів, насртопродуктів, а також їх змиву у водні басейни, переходу на екологічне землеробство 3 використанням альтернативних джерел енергії;

- покращення стану навколишнього середовища завдяки зменшенню навантаження на насртопереробну та хімічну промисловість, їх можливу переорієнтацію на виробництво органічних добрив та біопалива тощо;

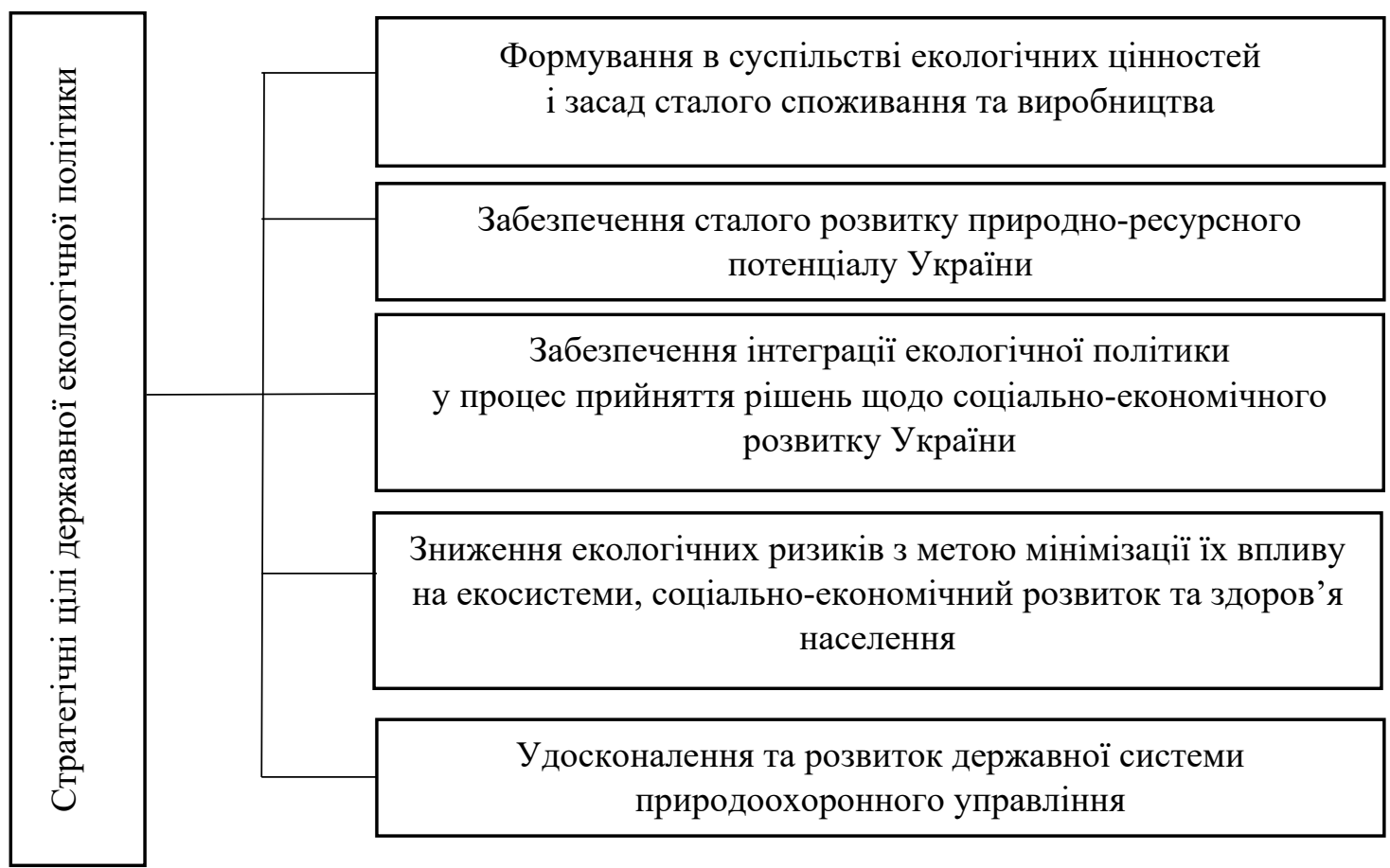

Рис. 1. Стратегічні цілі державної екологічної політики Джерело: побудовано авторами на основі [6] 
- забезпечення населення країни екологічно чистою продукцією;

- досягнення стабільного існування екосистеми;

- зменшення ризиків для здоров'я та життя людей;

- підвищення привабливості сільськогосподарської продукції вітчизняного виробництва для іноземних покупців, а підприємств-виробників даної продукції - для інвесторів;

- запобігання катастроф техногенного та екологічного характеру;

- зниження ставки екологічного податку, екологічних ризиків та ін.

Екологічна спрямованість інноваційного розвитку сільськогосподарських підприємств з одного боку буде сприяти розповсюдженню виробництва більш якісної та екологічно чистої продукції, покращенню здоров'я населення, а 3 іншого - прискорить технологічний прогрес та покращить соціально-економічне становище даних підприємств. Реалізація управлінських стратегій в даному випадку передбачає, окрім спеціальних знань та врахування особливостей ведення сільськогосподарського виробництва, також розширення знань, навичок та вмінь щодо ведення агробізнесу на екологічних та інноваційних засадах, здатність до виконання нових фрункцій, фрормування у керівників всіх структурних підрозділів інноваційного та екологічного мислення.

Виходячи 3 результатів проведеного дослідження, пропонуємо модель стратегічного управління інноваційним розвитком сільськогосподарських підприємств на екологічних засадах, яка поєднує в собі: інноваційні стратегії; екологічні стратегії та управлінські стратегії (рис. 2).

Поєднання даних стратегій в одній, на наш погляд, дозволить вирішити комплекс соціально-економічних та екологічних завдань, які сьогодні стоять як перед окремими підприємствами так і перед державою в цілому, а також створить умови для отримання синергетичного ефректу від взаємодії всіх складових запропонованої моделі.

3 метою практичної реалізації моделі стратегічного управління інноваційним розвитком сільськогосподарських підприємств на екологічних засадах пропонуємо виконати наступні заходи:

1) повна модернізація виробництва та реалізації сільськогосподарської продукції, 3 переходом на сучасні інноваційні та екологічні техніки та технології;

2) збалансований розвиток сільського господарства та галузей, що виготовляють для

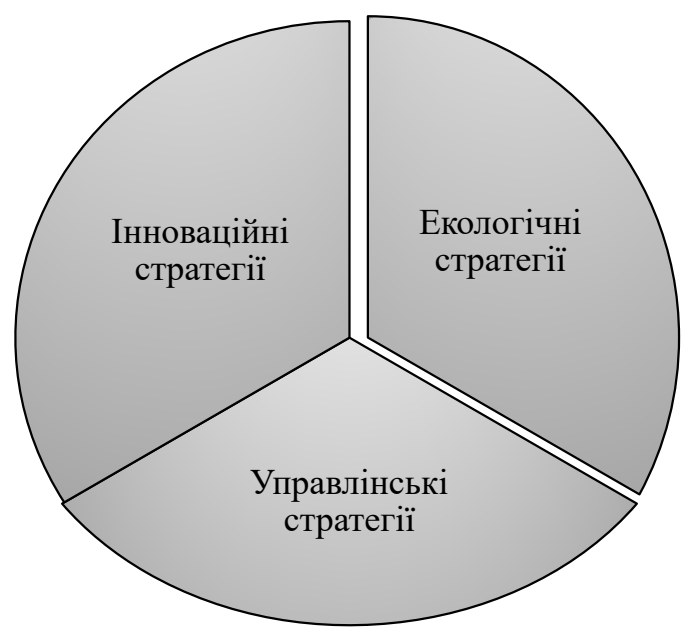

Рис. 2. Модель стратегічного управління інноваційним розвитком підприємств на екологічних засадах

Джерело: побудовано авторами

переробної промисловості та сільського господарства засоби виробництва, а також галузей з промислової переробки сільськогосподарської продукції;

3) впровадження систем екологічної та інноваційної політики за прикладом країн Європейського Союзу;

4) забезпечення підприємств кадрами відповідної кваліфікації;

5) пошук джерел фрінансування інноваційної діяльності сільськогосподарських підприємств на екологічних засадах;

6) удосконалення організаційної структури управління, запровадження сучасних управлінських практик та способів мотивації праці;

7) створення мобільних систем моніторингу якості земельних та водних ресурсів, атмоссрерного повітря;

8) запровадження міжнародних стандартів систем екологічного управління на підприємствах, реалізація міжнародних природоохоронних ініціатив;

9) інтеграція екологічної політики підприємств та країни до інших політик;

10) сприйняття та готовність працівників до реалізації еколого орієнтованих стратегій інноваційного розвитку підприємства.

Висновки. Комплекс заходів стратегічного управління сучасним сільськогосподарським підприємством має містити розробку та впровадження екологічно спрямованих інновацій. Модель управління підприємством заснована на інноваційному типі розвитку дозволить підтримувати його фрункціонування на високому технікотехнологічному рівні, покращити якісні характе- 
ристики продукції, довести їх до міжнародних стандартів, завоювати міцні позиції на світовому ринку, знизити податковий тиск та підвищити ефеективність діяльності в цілому, а екологічні засади такого розвитку сприятимуть покра- щенню іміджу та репутації підприємства тощо. Сукупність таких підходів в управлінні, в свою чергу, сприятимуть досягненню головної мети будь-якого підприємства - максимізації прибутку та забезпеченню його стійкого розвитку.

\section{СПИСОК ВИКОРИСТАНИХ ДЖЕРЕЛ:}

1. Ансоффф И. Стратегическое управление / перевод с англ. Москва, 2011. 519 с.

2. Багорка М.О., Юрченко Н.І. Екологічна спрямованість інноваційної діяльності аграрних підприємств. Вчені записки ТНУ імені В.І. Вернадського. Серія : Економічні науки. 2020. Т. 31(70). № 3. С. 107-113.

3. Білінська В. Сучасні інноваційні технології в сільському господарстві: основна характеристика та перспективи впровадження. Вісник Київського національного університету імені Тараса Шевченка. Економіка. 2015. Вип. 7. С. 74-80.

4. Брич В.Я., Снігур Х.А., Тисько М.М., Шпак Я.О. Управління інноваційним розвитком підприємства : монографрія. Тернопіль : ТНЕУ, 2019. 216 с.

5. Гудзинський О.Д., Судомир С.М., Гуренко Т.О. Менеджмент підприємницької діяльності : навчальний посібник. Київ : ІПК ДСЗУ, 2011. 71 с.

6. Закон України «Про Основні засади (стратегію) державної екологічної політики України на період до 2030 року» (2019 рік). URL: https://zakon.rada.gov.ua/laws/show/2697-19\#Text (дата звернення: 27.12.2021).

7. Ковтуненко К.В., Пар'єва О.О. Стратегічне управління інноваційним розвитком підприємства: сутність, класифікація стратегій. Економічний журнал Одеського політехнічного університету. 2020. № 2(12). C. 128-139. URL: https://economics.opu.ua/ejopu/2020/No2/128.pdf (дата звернення: 25.12.2021).

8. Міністерство освіти і науки України. URL: http://mon.gov.ua/ua

9. Осовська Г.В., Юшкевич О.О., Завадський Й.С. Економічний словник. Київ : Кондор, 2019. 358 с.

10. Офріційний сайт Державної служби статистики України. URL: http://www.ukrstat.gov.ua/

11. Рогоза М.Є., Вергал К.Ю. Стратегічний інноваційний розвиток підприємств: моделі та механізми : монографрія. Полтава : РВ ПУЕТ, 2011. 136 с.

12. Писаренко Т.В., Куранда Т.К., Кваша Т.К. та ін. Стан науково-інноваційної діяльності в Україні у 2020 році : науково-аналітична записка. Київ : УкрIHTEI, 2021. 39 с.

13. Шубравська О.В. Інноваційні транссормації агропродовольчого сектору економіки: світові тенденції та вітчизняні реалії. Економіка і прогнозування. 2010. № 3. С. 90-102.

14. Шубравська О.В., Прокопенко К.О. Розвиток агроінновацій в Україні. Економіка АПК. 2013. № 4. С. 77-81.

\section{REFERENCES:}

1. Ansoff, I. (2011) Strategicheskoye upravleniye [Strategic management] / perevod s angl. Moscow. (in Russian)

2. Bagorka, M., \& Yurchenko, N. (2020) Ekolohichna spryamovanist' innovatsiynoi diyal'nosti ahrarnykh pidpryyemstv [Environmentaly directed innovations in the activities of agricultural enterprises]. Vcheni zapysky TNU imeni V.I. Vernads'koho, 31(70), 3, 107-113. (in Ukrainian)

3. Bilinska, V. (2015) Suchasni innovatsiyni tekhnolohiyi v silskomu hospodarstvi: osnovna kharakterystyka ta perspektyvy vprovadzhennya [Modern innivative technologies in agriculture: main characteristics and prospects of implementation]. Visnyk Kyyivskoho natsionalnoho universytetu imeni Tarasa Shevchenka. Ekonomika, 7, 74-80. (in Ukrainian)

4. Brich V.Ya. (2019) Upravlinnya innovatsiynym rozvytkom pidpryyemstv [Management of innovative development of the enterprise]: monograph. Ternopil: TNEU. (in Ukrainian)

5. Hudzynskyy O.D., Sudomyr S.M., Hurenko T.O. (2011) Menedzhment pidpryyemnytskoyu diyalnosti: navchalnyi posibnyk [Business management: textbook]. Kyiv: IPK DSZU. (in Ukrainian)

6. Zakon Ukrayiny "Pro osnovni zasady (stratehiyu) derzhavnoyi ekolohichnoyi polityky Ukrayiny na period do 2030 roku" [Law of Ukraine "On the basic principles (strategy) of the state enveronmental policy of Ukraine for the up to 2030"] (2019). Retrieved 27 December, 2021. Retrieved from: https://zakon.rada.gov.ua/laws/show/2697-19\#Text

7. Kovtunenko, K.V., \& Pareva, O.O. (2020) [Strategic management of innovative development of the enterprise: essence, classification of strategies]. Economichnyi zhurnal Odes'koho politekhnichnoho universytetu, 2(12), 128-139. Retrieved 25 December, 2021. Retrieved from: https://economics.opu.ua/ejopu/2020/No2/128.pdf (in Ukrainian)

8. Ministerstvo osvity i nauky Ukrayiny. Retrieved 10 January, 2022. Retrieved from: http://mon.gov.ua/ua 
9. Osovska, H.V., Yushkevych, O.O., \& Zavadskyi, Y.S. (2009) Economichnyi slovnyk [Economic Dictionary]. Kyiv: Kondor.

10. State Statistics Service of Ukraine (2021) Derzhkomstat, Kyiv, Ukraine. Retrieved 12 January, 2022. Retrieved from: http://www.ukrstat.gov.ua/

11. Rogoza, M.E. (2011) Stratehichnyy innovatsiynyy rozvytok pidpryyemstv: modeli ta mekhanizmy [Strategic innovative development of enterprises: models and mechanisms]: monograph. Poltava: RVV PUET. (in Ukrainian)

12. Pysarenko, T.V., Kuranda, T.K., Kvasha, T.K. \& et al. (2021) Stan naukovo-innovatsiinoi diialnosti v Ukraini u 2020 rotsi: naukovo-analitychna zapyska [The state of scientific and innovative activity in Ukraine in 2020: scientific and analytical note]. Kyiv: UkrINTEl. (in Ukrainian)

13. Shubravs'ka, O.V. (2010) Innovatsiyni transformatsiyi ahroprodovol'choho sektoru ekonomiky: svitovi tendentsuyu ta vitchyznyani realiyi [Innovative transformations of the agri-food sector of the economy: global trends and domestic realities]. Ekonomika i prohnozuvannya, 3, 90-102. (in Ukrainian)

14. Shubravs'ka, O.V., Prokopenko, K.O. (2013) Rozvitok ahroinnovatsiy v Ukrayini [Development of Agro innovations in Ukraine]. Ekonomika APK, 4, 77-81. (in Ukrainian) 